\title{
Congenital Dental Disorder
}

National Cancer Institute

\section{Source}

National Cancer Institute. Congenital Dental Disorder. NCI Thesaurus. Code C35658.

A non-neoplastic dental disorder that is present at birth. 